A look at the region

\title{
Environmental Archaeology at the Czech University of Life Sciences Prague - An Application of New Methods for Interdisciplinary Research
}

\author{
Michal Hejcman ${ }^{a^{*}}$, Pavla Hejcmanováb, Petra Hlásná-Čepkovác, Jan Horáka , Petr Karlík ${ }^{\mathrm{d}}$, Vilém Pavlůa, \\ Richard Rosenberg ${ }^{d}$, Kateřina Součkováa ${ }^{\text {, Pavla Staňkováa }}$, Michaela Stejskalováa \\ ${ }^{a}$ Department of Ecology, Faculty of Environmental Sciences, Czech University of Life Sciences Prague, Kamýcká 129, CZ-165 21 Prague, Czech Republic \\ ${ }^{b}$ Department of Animal Science and Food Processing, Faculty of Tropical AgriSciences, Czech University of Life Sciences Prague, Kamýcká 129, \\ CZ-165 21 Prague, Czech Republic \\ ${ }^{c}$ Department of Crop Sciences and Agroforestry, Faculty of Tropical AgriSciences, Czech University of Life Sciences Prague, Kamýcká 129, \\ CZ-165 21 Prague, Czech Republic \\ ${ }^{d}$ Department of Forest Ecology, Faculty of Forestry and Wood Sciences, Czech University of Life Sciences Prague, Kamýcká 129, \\ CZ-165 21 Prague, Czech Republic
}

\section{ARTICLE INFO}

\section{Article history:}

Received: 1. December 2013

Accepted: 10.December 2013

\section{Keywords:}

enviromental archaeology

soil, plant and animal science

agronomy

genetics

ecology

phytoindication

\begin{abstract}
A BSTRACT
The research team of Environmental Archaeology was established by Prof. Michal Hejcman and his collaborators and students in the year 2008 and has been focused on performing modern interdisciplinary archaeological research directly connected with natural and agricultural disciplines such as soil, plant and animal sciences, agronomy, genetics and ecology. We focus on research into chemical signatures in archaeological soils; livestock feeding in the past - leaf fodder and year-round livestock grazing in particular; the use of cropmarks for identification of archaeological features on contemporary arable fields, phytoindication - the use of contemporary plant species composition of grasslands and forests for the detection of archaeological features and former land use; origin, spread and reproduction mechanisms of ornamental and medicinal plants (Vinca minor in particular) used by our ancestors in Central Europe; and experimental planting of prehistoric crops and their nutritive value, Triticum dicoccum in particular. We publish the results of our research activities on an ongoing basis in international journals.
\end{abstract}

\section{Introduction}

The research team of Environmental Archaeology was established by Prof. Michal Hejcman and his collaborators and students in the year 2008 and has been focused on performing modern interdisciplinary archaeological research directly connected with natural and agricultural disciplines such as soil, plant and animal sciences, agronomy, genetics and ecology. The aim of the team is to integrate the natural sciences with archaeological research and develop new methods directly applicable in archaeological field research and consequent interpretations. The results of this young research team are

*Corresponding author. E-mail: hejcman@fzp.czu.cz published on an ongoing basis in international journals such as Agriculture, Ecosystems and Environment (Hejcman, Smrž 2010), Ecosystems (Hejcman et al. 2013a), Grass and Forage Science (Hejcman et al. 2013b), The Holocene (Hejcman et al. 2014), Interdisciplinaria Archaeologica - Natural Sciences in Archaeology (Součková et al. 2013), Journal of Archaeological Science (Gojda, Hejcman 2012), Plant and Soil (Hejcman et al. 2011, 2013c), Quaternary International (Hejcman et al. 2013d), Soil and Water Research (Horák, Hejcman 2013) and Vegetation History and Archaeobotany (Hejcmanová et al. 2014).

The primary research activities of the team consist of developing new methods for analyses and interpretation of chemical signatures preserved in archaeological soils, studying the principles of cropmarks which are used for 
the identification of archaeological features in stands of contemporary crops by means of remote sensing, studying phytoindication - the use of contemporary plant species composition of grasslands and forests for detection of archaeological features, studying models of livestock foddering in prehistory using recent analogies and analyses of the forage quality of fodder plants, studying prehistoric arable agriculture using archaeological experiments, studying landscape history using recent vegetation cover in connection with written records and old maps and finally, studying origin, spread and reproduction mechanisms of ornamental and medicinal plants used by our ancestors in Central Europe.

\section{The main research activities in detail}

\subsection{Chemical signatures in archaeological soils}

It has been well known since the times of Arrhenius (1931) that ancient settlement activities are connected with an increased concentration of phosphorus in archaeological soils and sediments. So-called "phosphate analysis" is routinely used in field archaeological research in many countries (Terry et al. 2000; Erneé 2005; Roos, Nolan 2012), although phosphate analysis alone does not enable the identification of the phosphorus origin and various other details concerning ancient human activities. In addition, phosphates can be extracted by different solutions from the soil and the results of different authors are thus incomparable and do not enable comparisons over wide regions (see Holliday, Gartner 2007). In our research efforts, we successfully applied the Mehlich 3 extraction procedure and determined the concentrations of plant available macro ( $\mathrm{P}, \mathrm{K}, \mathrm{Ca}, \mathrm{Mg}$ ), micro (Fe, $\mathrm{Zn}, \mathrm{Mn}, \mathrm{Cu}$ ) and risk (As, $\mathrm{Cd}, \mathrm{Pb}$ ) elements in various archaeological soils using this solution (see Figure 1 for the collection of different archaeological soils). We propose the use of the Mehlich 3 extraction solution as an international standard method for analysis of archaeological soils (Hejcman et al. 2013d). The Mehlich 3 extraction
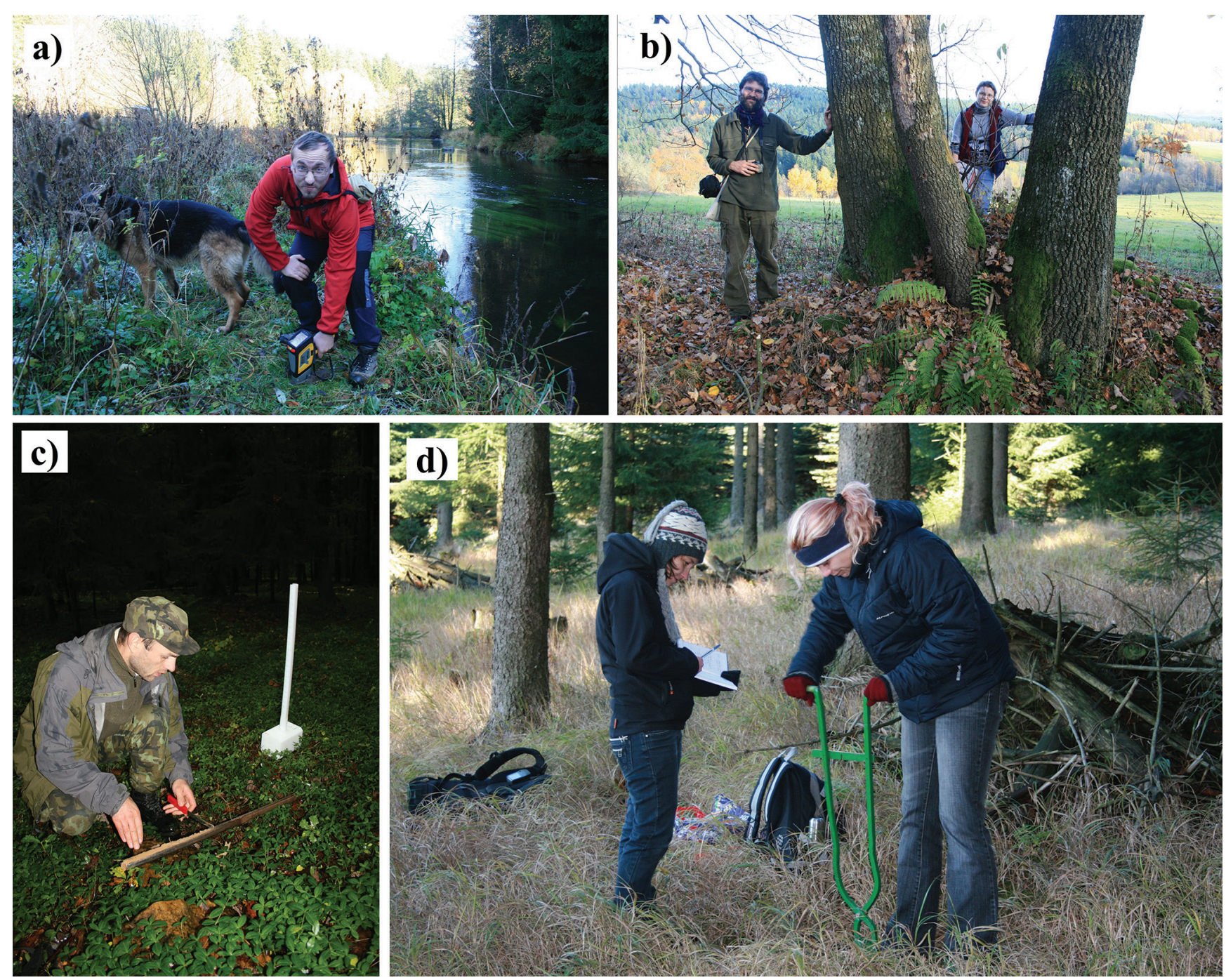

Figure 1. a) Jan Horák during the field research of chemical composition of alluvial sediments of the Ohře (Eger) river using a XRF device in Fichtelgebirge Mts. (Germany) in October 2013, b) Petr Karlík and Pavla Staňková during the field non-destructive research of agrarian terraces in the deserted village of Malonín (Czech Republic) in October 2013, c) Michal Hejcman during sampling of archaeological soils in a stand of Vinca minor in the deserted medieval village of Roudnička (Bohemian forest, Czech Republic) in November 2010 and d) Kateřina Součková and Pavla Staňková during soil sampling on former medieval arable fields in the deserted village of Spindelbach (Ore Mts., Czech Republic) in October 2011. 
solution is a standard agrochemical method used in the Czech Republic and Slovakia and also in certain states of the USA for agrochemical testing of forest and agricultural soils. The advantage of the Mehlich 3 solution is that it can be used with a wide spectrum of soils from acid to alkaline and from forests through grasslands up to arable soils. Numerous elements can consequently be determined in one extract and the obtained data can be compared with the database of soil chemical properties gathered by the Central Institute for Supervising and Testing in Agriculture based on results obtained from agrochemical testing of soils in the Czech Republic (Klement et al. 2012). Human settlement activities are well detectable according to increased concentrations of plant available $\mathrm{P}, \mathrm{Ca}, \mathrm{Mg}, \mathrm{Zn}$ and $\mathrm{Cu}$ in archaeological soils in comparison with control soils in the study area (Hejcman et al. 2011; 2013a; 2013c). Additional soil properties which can provide useful information for interpretation of anthropogenic activities consist of soil reaction, content of organic $\mathrm{C}$, total $\mathrm{N}, \mathrm{C}: \mathrm{N}$ ratio and $\mathrm{N}$ isotopes (Hejcman et al. 2013d; Součková et al. 2013). Based on our experience, the chemical signatures of human activities are well preserved in fills of sunken subsoil archaeological features in comparison with control samples from their surroundings, but also in contemporary arable layers despite long-term ploughing and fertilizer application on arable fields (Hejcman et al. 2011; 2013c). In contrast to artefacts, the information hidden in the chemical signature of archaeological soils has frequently been neglected during archaeological excavations although detailed analysis of soils can answer many challenging archaeological as well as environmental questions such as: whether the soil material used for the construction of the barrow or fortification or the area beneath the barrow or fortification was affected by previous human settlement, metal or pottery production activities; whether the layering recorded on the archaeological locality represents real archaeological layers generated by human activities or instead soil horizons developed by natural soil forming processes; whether the dark layers recorded beneath the
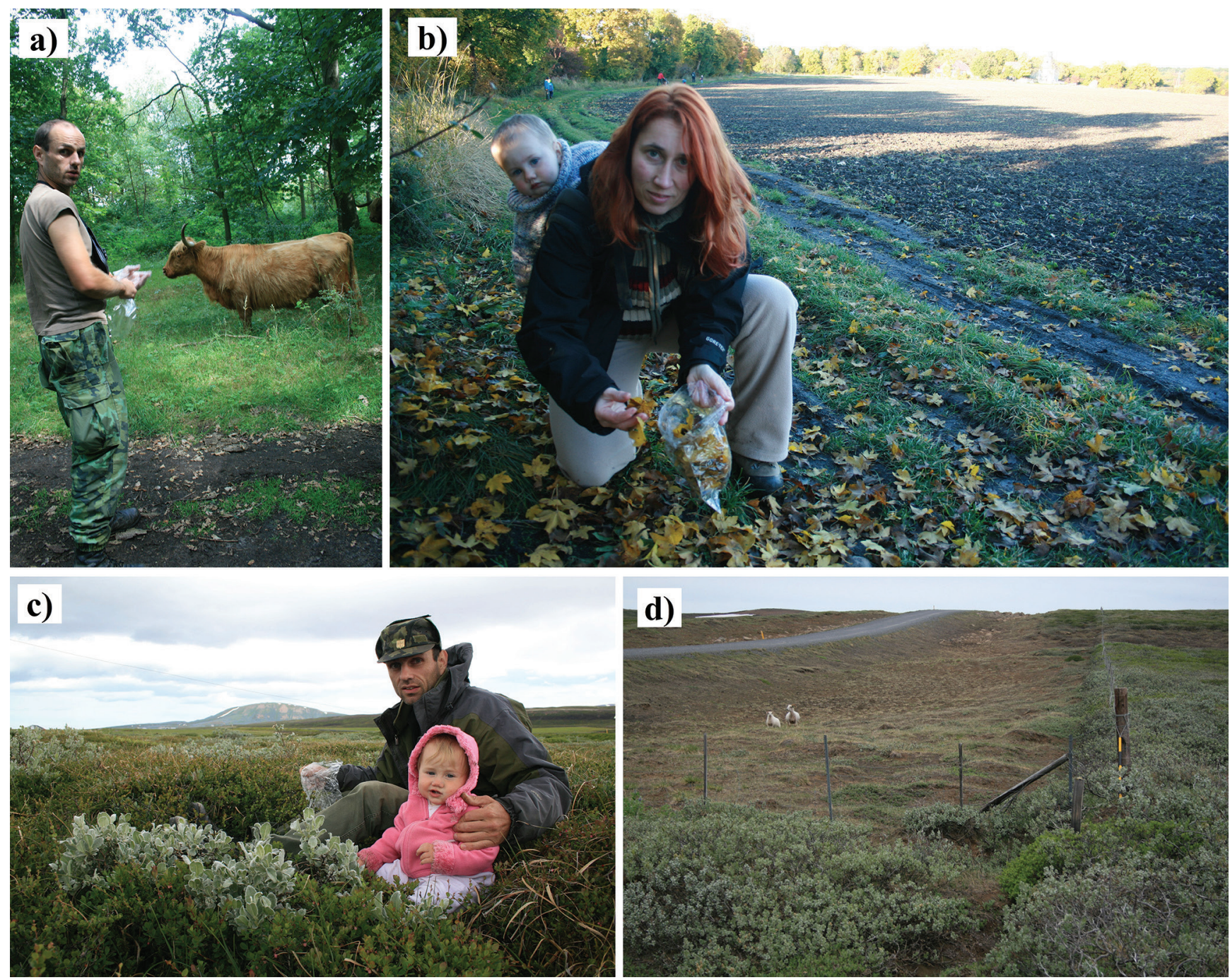

Figure 2. a) Michal Hejcman during the collection of Highland cattle faeces in the Kraansvlak national park in the Netherlands in August 2013, b) Pavla and Amálie Hejcmanová during the collection of abscised leaves of Acer campestre for an analysis of their nutritive value in Dřevíc (Czech Republic) in October 2013, c) Michal Hejcman (with Amálie) during the collection of leaf fodder samples of Salix lanata in Iceland in June 2013, d) intensive sheep grazing is able to completely eliminate Salix shrubby vegetation in Iceland. 
barrow or fortification represents paleo soil and how is the fertility of this paleo soil different from the contemporary soils at the study site; how contamination by trace elements (As, $\mathrm{Cd}, \mathrm{Cu}, \mathrm{Pb}$ and $\mathrm{Zn}$, for example) differs between paleo and recent soils? How intensive were ancient human settlement activities in the locality and how much did they affect the productivity of contemporary ecosystems? How intensive were mining and metal production activities in the landscape and how much did they affect the contamination of soils and alluvial sediments?

We recently began to use X-ray fluorescence (XRF) analysis for determination of total concentrations of a wide spectrum of elements in archaeological soils (Figure 1a). The advantage of XRF is the low price of the analyses, the wide spectrum of the determined elements and immediate information concerning the chemical composition of the analysed soils directly in the field. The first studies by our team using XRF analyses of archaeological soils are now being prepared for publication.

\subsection{Livestock feeding in the past - the use of leaf fodder and year-round livestock grazing in forests}

Livestock breeding and consequently grazing and fodder production activities have highly affected natural and seminatural vegetation in many countries since the Neolithic (see Figure 2 for leaf fodder collection and livestock feeding research). The bottle-neck for livestock breeding was the winter time and therefore the winter feeding of livestock was the most crucial for its survival in the regions of Central and Northern Eurasia. Livestock foddering ranks among frequently discussed topics amongst archaeologists, although these discussions are frequently without any background data connecting physiological and nutritional requirements of fodder plants and livestock. To fill this gap,
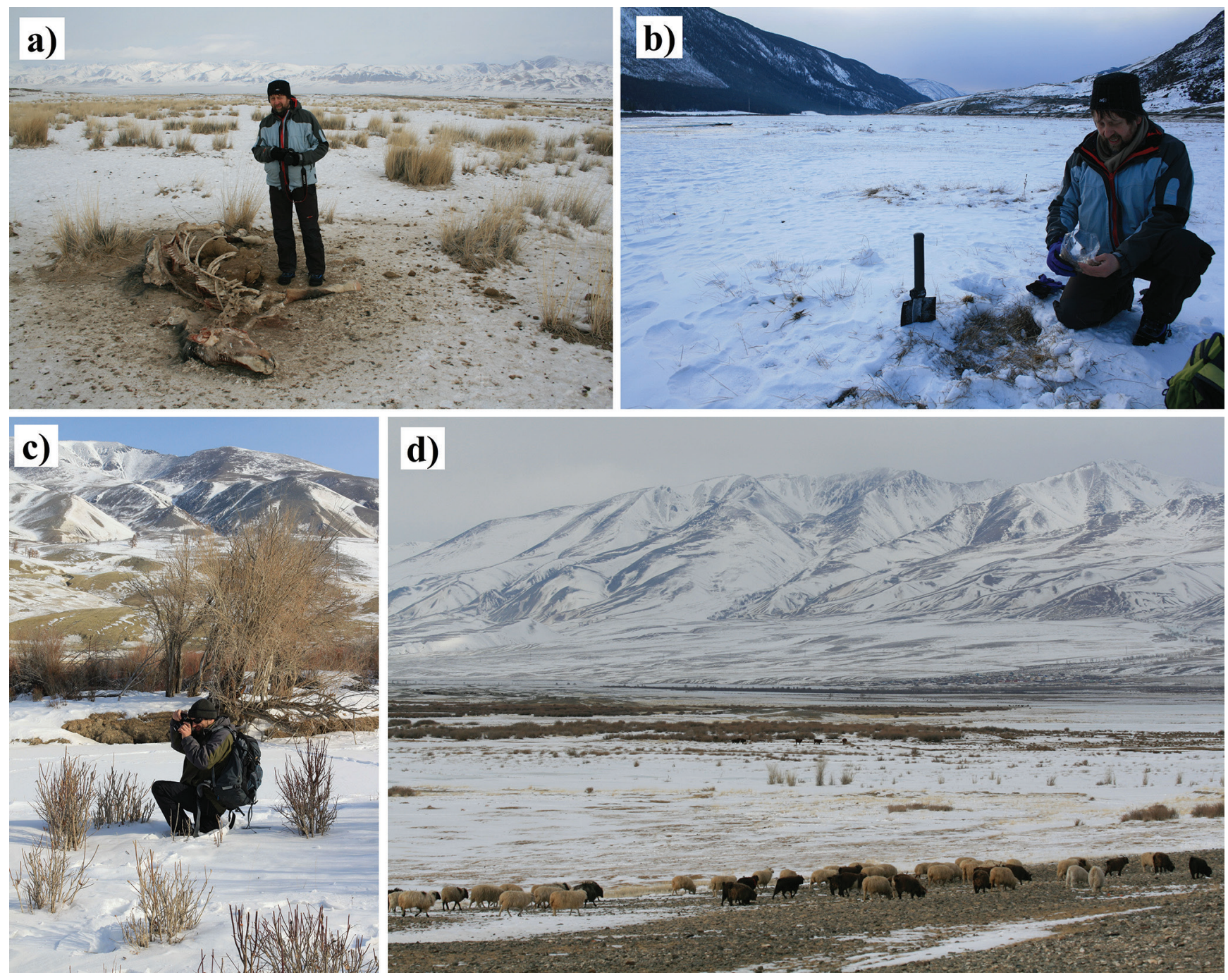

Figure 3. Winter expedition into the Altai Mts. (Russia) in February and March 2013 - a recent analogy with Pleistocene winter pastures in Central Europe and also with prehistoric year-round livestock grazing. a) Vilém Pavlů with a deceased horse on tall steppe grassland used as a winter pasture, b) Vilém Pavlů collects senescent grassland biomass for analysis of its nutritive value. Senescent grassland biomass (litter) is the principal livestock winter forage if the snow cover is under $20 \mathrm{~cm}$. c) Michal Hejcman in an alluvial forest with Salix sp. and Populus sp. shrubs heavily damaged by livestock (sheep, cattle and horses) winter browsing. We are of the opinion that alluvial forests were similarly utilized by livestock in Central Europe in prehistory. d) Sheep and cattle on winter pastures with a thin snow layer. 
we have studied livestock feeding using modern analytical methods for determination of the forage quality of various fodder species. As wintertime was the most critical for the survival of livestock, we focus on leaf fodder quality and also on the quality of winter available biomass such as the litter of grassland species, annual twigs, bark and abscised leaves of woody species from South Siberia, through Europe, Africa up to the North Atlantic Isles. Based on our first published results, we concluded that the retreat of high quality forage woody species (Acer, Fraxinus, Tilia, Ulmus) and their replacement with low forage quality woody species (Carpinus, Fagus) in many regions of Central Europe in prehistory could be directly connected with year-round livestock grazing and leaf fodder collection (Hejcman et al. 2014; Hejcmanová et al. 2014). In addition, based on our personal experience with winter feeding of livestock in the Altai Mts. (expedition by M. Hejcman and V. Pavlů in February and March 2013, Figure 3), we concluded that the majority of livestock in Central Europe in prehistory was able to survive the winter without any supplementary feeding. Supplementary feeding and stalling of livestock was necessary in regions with long lasting snow cover over $20 \mathrm{~cm}$. Livestock most probably grazed the litter of grassland species and the living biomass of winter green species (Hedera, Rubus, Viscum) and browsed the annual twigs of woody species, Populus, Salix, Tilia and Ulmus, in particular, because of their highest forage quality.

Although leaf fodder collection and year-round livestock grazing was also extremely important for livestock based farming systems and consequently deforestation on isles in the Northern Atlantic, this topic has never been studied using a modern analytical approach. We began to study the forage quality of leaf fodder and the use of woody species (Betula nana, B. pubescens, Salix lanata, S. phylicifolia, Sorbus aucuparia) for livestock feeding by Norse farmers in Iceland in June 2013 (Figures 2c, 2d).

\subsection{The use of cropmarks for identification of}

archaeological features on contemporary arable fields The majority of prehistoric archaeological features are buried in the sub-soil of contemporary arable fields in Central Europe. The plants are also able to absorb scarce water and nutrients from sub-soil layers and therefore the character of the sub-soil layers is well reflected by crop growth. Sub-soil archaeological features such as sunken buildings, granaries, waste pits, post holes, graves and ruins of stony buildings can thus be discovered due to visually detectable changes in crop growth, termed cropmarks, which are well detectable on aerial photographs. As of the 1990s, more than one thousand archaeological localities have been discovered according to cropmarks by means of archaeological remote sensing (syn. aerial archaeology) in Bohemia, the western part of the Czech Republic (Hejcman, Smrž 2010; Gojda, Hejcman 2012). The best crop for identification of archaeological features is barley (Hordeum vulgare) as this crop has the most responses to variability in the soil profile in terms of colour and height changes out of the frequently planted crops in Europe. Positive cropmarks (improved crop growth on the archaeological feature) are frequently connected with substantial improvement of the crop N, P, K, Ca, Mg and $\mathrm{Zn}$ nutrition. We have been amongst the first to analyse the availability of nutrients in archaeological soils and demonstrate that the nutrients accumulated in archaeological sub-soil features can be directly taken up by contemporary crops (Hejcman et al. 2011; Hejcman et al. 2013c). Modern crops and their chemical composition are thus an important source of archaeological information concerning archaeological features. Almost all human settlement activities have been connected with the accumulation of nutrients in the settled area, due to deposition of organic wastes and wood ash. We also discovered that the oldest mineral $\mathrm{P}, \mathrm{K}, \mathrm{Ca}, \mathrm{Mg}$ and $\mathrm{Zn}$ fertilizer was wood ash, in all probability intentionally used for improvement of crop growth and its nutritional value for humans since the beginnings of the agriculture in the Mesolithic-Neolithic transition. Another source of nutrients for plants are graves, with one human body in a grave representing a huge amount of $\mathrm{N}, \mathrm{P}$ and $\mathrm{Ca}$, and with the position of a grave on nutrient poor soils serving to irreversibly improve crop nutrition. As the nutrients from the decomposed human body are continuously taken up by contemporary crops, each person in Europe is at least partly "cannibal" as we are continuously eating nutrients which were in the bodies of our ancestors. Plants are able to find nutrient rich patches in graves and explore them with their roots. This succinctly explains why bones in graves are surrounded by the roots of contemporary plants even in the case of graves which are three metres beneath the contemporary soil surface. Plantgrave and other archaeological feature interactions are part of our contemporary research and the results of this research are being prepared for publication on an ongoing basis.

\subsection{Phytoindication - the use of contemporary plant species composition of grasslands and forests for the detection of archaeological features and former land use}

In ecosystems composed from numerous plant species such as grasslands and forests, plant species composition can be made use of for detection of archaeological features. Although the principle of phytoindication is well known in archaeology, for example that the presence of Urtica dioica indicates sites with wastes and therefore nutrients deposition, exact studies documenting the use of phytoindication in field archaeological research are still rare. With the example of the deserted medieval village of Kří which existed ca. from 1357 to 1420 AD, we demonstrated that short-term human settlement activities can generate a truly huge variability in soil chemical properties which is well reflected by contemporary plant species composition of the forest understory (Hejcman et al. 2013a). The position of former buildings was well indicated, for example, by the yellow colour of Anemone ranunculoides at the time of its flowering in the early spring. The position of former buildings was also indicated by a substantially higher species richness of understory species in comparison with the former 
village square or gardens. This was due to the neutral soils of the former buildings in contrast to the acid soils in their surroundings: the majority of species in the flora of Central Europe are adapted to neutral and alkaline soils. An excellent indicator of deserted medieval villages in contemporary forests in the Czech Republic is Vinca minor, which has been planted as a medicinal and ornamental plant in all probability since prehistory and has survived in the territories of deserted villages for centuries (Nová, Karlík 2010). In the current research which is gradually being prepared for publication, we used the plant species composition of contemporary grasslands for identification of former land use in various regions of the Czech Republic and Germany. Phytoindication can thus be used in archaeological research on different spatial scales from an indication of individual features up to landscape studies. Phytoindication can be based not only to study current aboveground vegetation, but for analysis of the soil seed bank, since burial seeds can survive in the soil for a long period of time and can provide information about vegetation or land use in the past.

\subsection{The origin, spread and reproduction mechanisms of the ornamental and medicinal plants used by our ancestors in Central Europe}

Using the model species Vinca minor, which spreads in particular clonally in Central Europe, we decided to study its origin and the level of genetic variability by application of various molecular markers (e. g. Inter Simple Sequence Repeats, Simple Sequence Repeats and Amplified Fragment Length Polymorphism). We established a collection of plants collected at different archaeological localities such us prehistoric settlements, deserted medieval villages (Figure 1c) and cemeteries and compared them with plants collected at localities in contemporary villages and gardens. The plants were collected in Austria, the Czech Republic, Germany and Slovakia. Their genetic variability in Central Europe and its comparison with the variability in populations in the Mediterranean where the species is considered to be native can help us answer questions about alien status, the mechanisms of its reproduction in Central Europe and about the ways of its human intentional spreading.

Based on the knowledge about the population biology of $V$. minor, we developed a model concerning its clonal growth, which is used to assess the age of populations based on population size. We survey the distribution of $V$. minor in territories of deserted villages aiming to predict places of its planting in medieval villages or directly localize unknown deserted villages which are present in contemporary forests.

\subsection{Experimental planting of prehistoric crops - an example of the experiment with the cultivation of emmer wheat (Triticum dicoccum) in the open air museum Březno near Louny}

Taking into account insufficient information concerning planting and nutritive values of prehistoric crops, we recently established a working group for cultivation of prehistoric crops using prehistoric technologies. The first experiment with planting of Triticum dicoccum under simulated prehistoric conditions was established in spring 2013 in the open air museum in Březno near Louny in the NW part of the Czech Republic (Figure 4). In this region with highly fertile chernozem soils, $T$. dicoccum has been cultivated from the Neolithic up to the Migration period (Tempír 1982). In addition to scientific research, the experiment was directly used for education of visitors with its scientific aim being to compare soil properties, grain and straw yields, hulled index, the nutritive values of grain, glumes and straw, harvest index, plant height and weedy communities in a stand of T. dicoccum established on an old field used for crop production for several preceding years (hereafter referred to as the old field) and a stand of $T$. dicoccum established on a field converted from a permanent grassland by a hoe digging directly prior to seeding (hereafter referred to as the new field). To demonstrate the differences between old and modern technologies and cereals, the obtained data from the experiment with $T$. dicoccum were compared with a modern variety of T. aestivum planted via modern technology in the neighbourhood of the archaeological experiment (hereafter referred to as the modern field). The obtained results are now being prepared for publication. The main conclusions are as follows: It was really difficult to convert grassland into arable field using a scratch plough. The grasslands were in all probability converted into arable land using a hoe as this was the simplest way. There probably were not strict borders between the grasslands and arable fields. Many grassland species could have been weedy species in stands of cereals during prehistory. Despite the extremely high cover of weedy species, the grain (without glumes) yield of $T$. dicoccum was approximately $2 \mathrm{t} \mathrm{ha}^{-1}$ without any fertilizer application and weeding. The grain yield of T. aestivum on the modern field with $\mathrm{N}$ fertilizers application was approximately $5 \mathrm{tha}^{-1}$ and the field was without any weedy species. The concentrations of numerous macro and micro elements were substantially higher in T. dicoccum than in T. aestivum. Triticum dicoccum is thus a species with a high nutritive value for its grain.

\section{Conclusions}

Based on our research activities, we concluded that modern archaeology requires methods used in agronomy and natural sciences in order to answer new and challenging questions. In addition, archaeological experiments and recent analogies are required to answer questions connected with prehistoric agricultural production. We hope that the research activities of our team serve to help break up the frequent sharp borders between archaeologists and natural scientists.

\section{Members of the team and their expertise}

Michal Hejcman - leader of the team, soil science, agronomy, botany, plant and animal nutrition, agricultural history, ecology. 

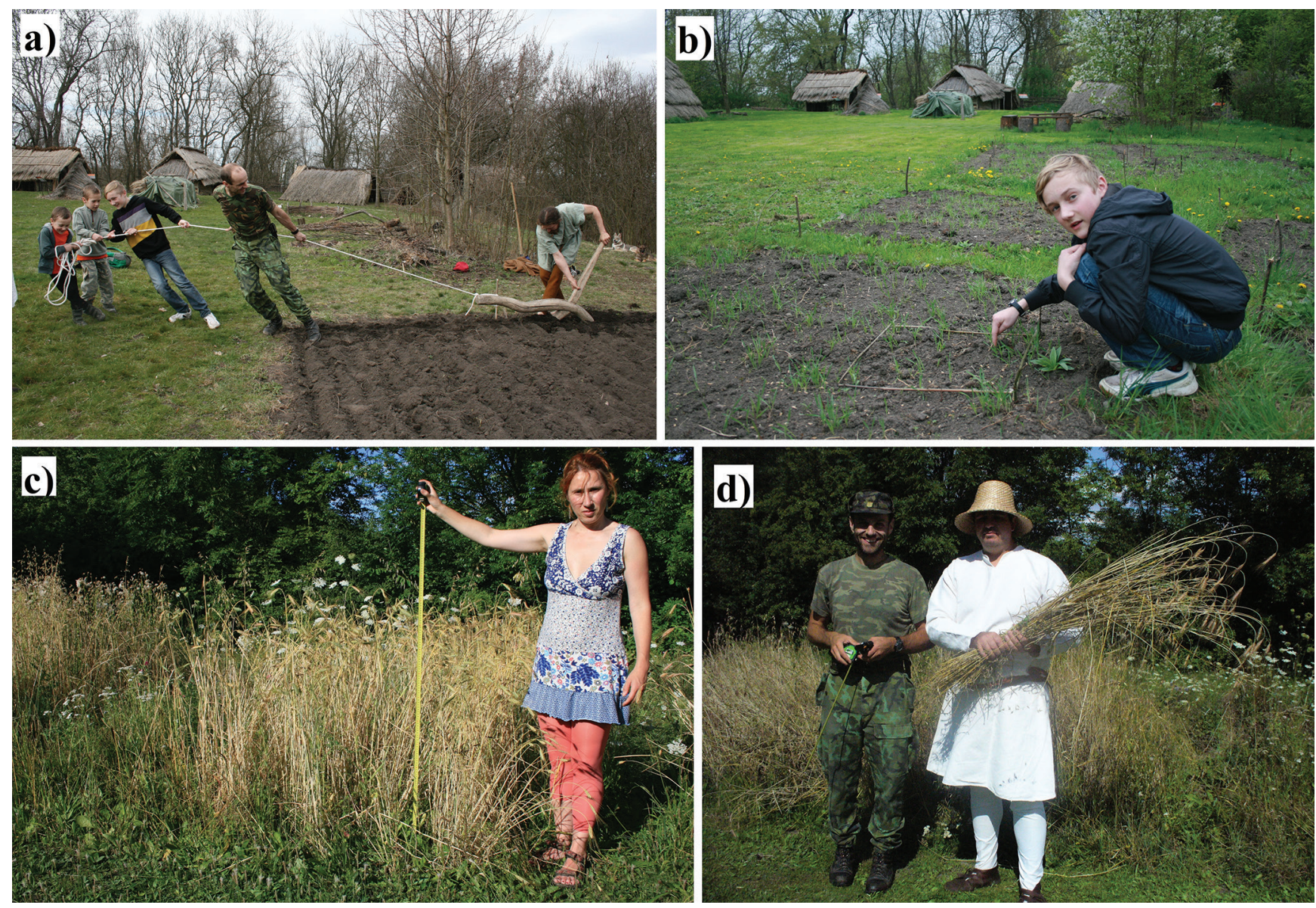

Figure 4. Experimental planting of Triticum dicoccum by prehistoric technology in the open air museum Březno near Louny (Czech Republic) in the vegetation season 2013. a) Jaroslav, Jan, Michal (jun.) and Michal (sen.) Hejcman in the role of draught animals during the experimental ploughing of the prehistoric field by Pavel Šroubek. b) Michal Hejcman (jun.) during the counting of seedlings of T. dicoccum in the experimental field, c) Pavla Hejcmanová during the measuring of the height of the T. dicoccum stand, d) Michal Hejcman and Richard Rosenberg during the harvest.

Pavla Hejemanová - animal nutrition and behaviour, leaf fodder, ecology of megaherbivores.

Petra Hlásná-Čepková - genetic methods.

Jan Horák - soil science, medieval archaeology.

Petr Karlík - vegetation ecology, conservation biology, historical geography, soil science.

Vilém Pavlů - livestock breeding, animal nutrition and behaviour, botany, landscape history and ecology.

Richard Rosenberg - medieval archaeology and agriculture.

Kateřina Součková - the use of nitrogen isotopes for detection of ancient farming practices.

Pavla Staňková - soil science, the use of nitrogen isotopes for detection of ancient farming practices.

Michaela Stejskalová - leaf fodder and animal behaviour.

\section{References}

ARRHENIUS, O. 1931: Die Bodenanalyse im Dienst der Archäologie. Zeitschrift für Pflanzenernährung,Düngung und Bodenkunde, Teil B 10, 427-439.

ERNEÉ, M. 2005: The use of soil phosphate analysis in the interpretation of Late and Final Bronze Age cultural stratigraphy and sunken features at Prague 10 - Záběhlice. Archeologické rozhledy 57, 303-330.
GOJDA, M., HEJCMAN, M. 2012: Cropmarks in main field crops enable the identification of a wide spectrum of buried features on archaeological sites in Central Europe. Journal of Archaeological Science 39, 16551664.

HEJCMAN, M., HEJCMANOVÁ, P., PAVLŮ, V., BENEŠ J. 2013b: Origin and history of grasslands in Central Europe - a review. Grass and Forage Science 68, 345-363.

HEJCMAN, M., HEJCMANOVÁ, P., STEJSKALOVÁ, M., PAVLŮ, V. 2014: Nutritive value of winter collected annual twigs of main European woody species, mistletoe and ivy and its possible consequences for winter foddering of livestock in prehistory. The Holocene, in press.

HEJCMAN, M., KARLÍK, P., ONDRÁČEK, J., KLÍR, T. 2013a: Shortterm Medieval Settlement Activities Irreversibly Changed Forest Soils and Vegetation in Central Europe. Ecosystems 16, 652-663.

HEJCMAN, M., ONDRÁČEK, J., SMRŽ, Z. 2011: Ancient waste pits with wood ash irreversibly increase crop production in Central Europe. Plant and Soil 339, 341-350.

HEJCMAN, M., SMRŽ, Z. 2010: Cropmarks in stands of cereals, legumes and winter rape indicate sub-soil archaeological features in the agricultural landscape of Central Europe. Agriculture, Ecosystems and Environment 138, 348-354.

HEJCMAN, M., SOUČKOVÁ, K., GOJDA, M. 2013c: Prehistoric settlement activities changed soil $\mathrm{pH}$, nutrient availability, and growth of contemporary crops in Central Europe. Plant and Soil 369, 131-140.

HEJCMAN, M., SOUČKOVÁ, K., KRIŠTUF, P., PEŠKA, J. 2013d: What questions can be answered by chemical analysis of recent and paleosols from the Bell Beaker barrow (2500-2200 BC) in Central Moravia, the Czech Republic? Quaternary International 316, 179-189. 
HEJCMANOVÁ, P., STEJSKALOVÁ, M., HEJCMAN, M. 2014: Forage quality of leaf-fodder from main broad-leaved woody species and its possible consequences for the Holocene development of forest vegetation in Central Europe. Vegetation History and Archeobotany. DOI 10.1007/ s00334-013-0414-2.

HOLLIDAY, V. T., GARTNER,W. G. 2007: Methods of soil P analysis in archaeology. Journal of Archaeological Science 34, 301-333.

HORÁK, J., HEJCMAN, M. 2013: Use of trace elements from historical mining for alluvial sediment dating. Soil and Water Research 8, 77-86.

KLEMENT, V., SMATANOVÁ, M., TRÁVNÍK, K. 2012: Fifty years of agrochemical testing of agricultural soils in the Czech Republic. Central Institute for Supervising and Testing in Agriculture, Brno.

NOVÁ, J., KARLÍK P. 2010: Vegetace zaniklých středověkých vesnic Kozelského polesí (Plzeňsko) [Vegetation of deserted medieval villages in the Kozel forest district (Pilsen region)]. Zprávy České Botanické Společnosti 45, 93-117.
ROOS, C. I., NOLAN, K. C. 2012: Phosphates, plowzones, and plazas: a minimally invasive approach to settlement structure of plowed village sites. Journal of Archaeological Science 39, 23-32.

SOUČKOVÁ, K., HEJCMAN, M., KLÍR, T. 2013: Medieval Farming Practices in Deserted Villages Can be Determined Based on the Nitrogen Isotopic Signature in Recent Forest Soils. Interdisciplinaria Archaeologica - Natural Sciences in Archaeology 4, 63-71.

TEMPÍR, Z. 1982: Zemědělske plodiny a plevele $\mathrm{z}$ archeologickych nalezů v Březně u Loun [Agricultural crops and weeds from archaeological findings in Březno by Louny]. Vědecké práce Zemědělského muzea 22, 121-195.

TERRY, R. E., NELSON, S. D., CARR, J., PARNELL, J. J., HARDIN, P. J., JACKSON, M. W., HOUSTON, S. D. 2000: Quantitative phosphorus measurement: a field test procedure for archaeological site analysis at Piedras Negras, Guatemala. Geoarchaeology 15, 151-166.

\section{Michal Hejcman - a scientific profile}

Prof. RNDr. Michal Hejcman, Ph.D. et Ph.D. is lecturer and researcher in the fields of agronomy, soil, plant and animal sciences, ecology and archaeology. He works in

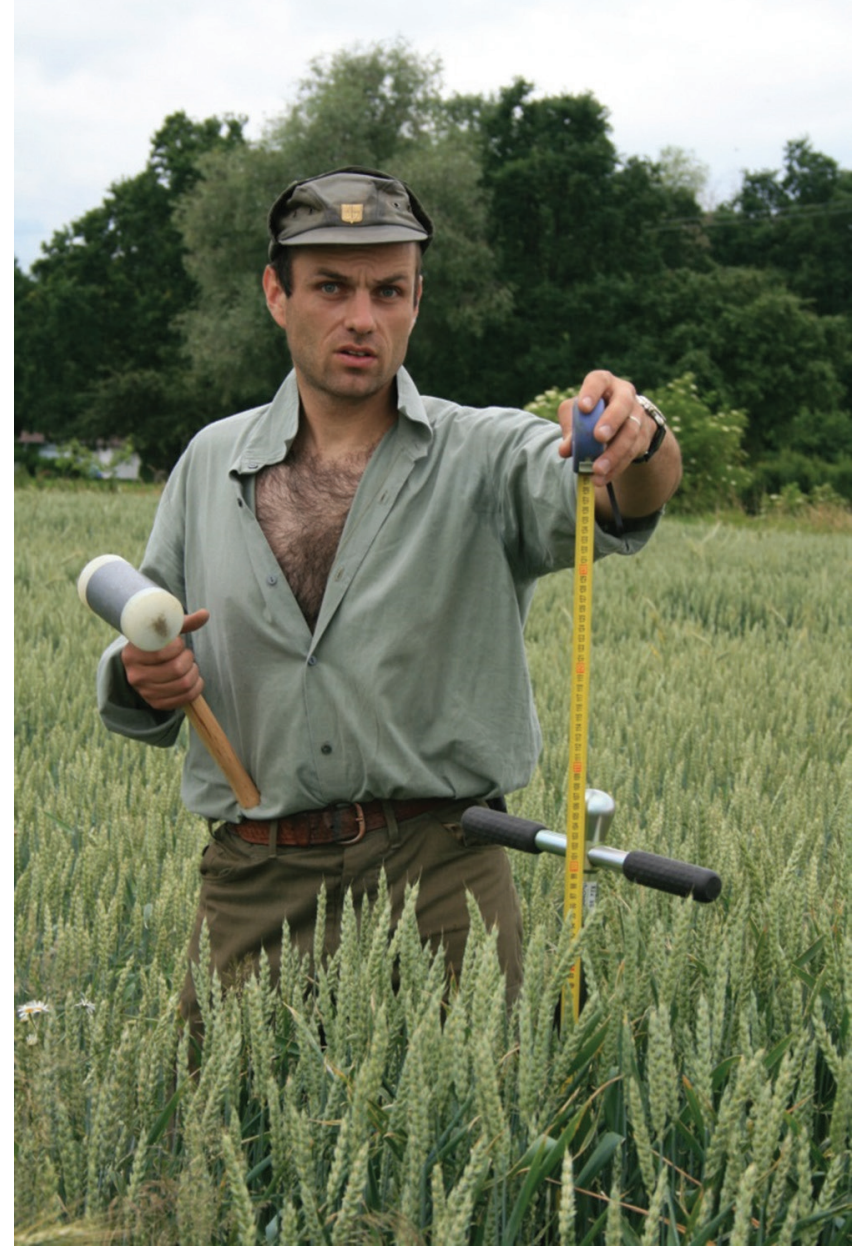

Figure 5. Michal Hejcman during the collection of soil samples and measuring the height of a Triticum aestivum stand in a positive cropmark at the archaeological locality of Drožkovice near Chomutov (NW Czech Republic) in 2009. the Department of Ecology at the Czech University of Life Sciences Prague where he is head of the Environmental Archaeology Research Team. He is active as a researcher in the field of agronomy at the Crop Research Institute PragueRuzyně with a particular interest in long-term soil fertility experiments and the planting of cereals. He is also a Ph.D. student of archaeology in the Department of Archaeology, University of Hradec Králové as of 2013.

He comes from a farmer family and has been interested in agriculture, natural sciences and archaeology, with the support of his father Ing. Ludvík Hejcman, since childhood. After graduating from the Agricultural High School in Hořice v Podkrkonoší in 1994, he studied geobotany at the Faculty of Sciences, University of South Bohemia in České Budějovice and graduated in 1999. He worked over the years 2000 - 2003 in the Krkonoše National Park Administration where he focused on ecology and management of mountain grasslands and on the history of mountain agriculture (Hejcman et al. 2005; 2006; 2007; 2009). He defended his first Ph.D. thesis "Grassland Management in Mountain and Upland Areas of the Czech Republic" at the Faculty of Environmental Sciences, Czech University of Life Sciences Prague in 2005. During his study of the Grass Garden, a grassland area in the surroundings of Luční bouda chalet in the Giant (Krkonoše) Mountains fertilized by manure and wood ash from at least the $17^{\text {th }}$ century up to 1944 (Semelová et al. 2008), he detected the effects of fertilizer application on soil chemical properties and plant species composition 62 years after the last fertilizer application. This was a crucial step for his deep interest in the chemical signatures of archaeological soils and for the study of archaeology. He intensively studied methods used in soil science, plant and animal nutrition (with the support of Dr. Jürgen Schellberg, University of Bonn) and defended this topic in his second Ph.D. thesis "The Effect of Fertilizer Application on Grasslands: what can it tell us Long-Term Experiments" at the Faculty of Sciences, Charles University in Prague in 2010. In 2007, he defended his habilitation thesis "Methods of Data Collection in Vegetation Science: An Observational and Experimental Approach" and became Associate 
Professor in the field of ecology at the Czech University of Life Sciences Prague where he also became University Professor in the field of ecology in 2011. He began with the establishment of a "Team of Environmental Archaeology" at the Czech University of Life Sciences Prague in 2008. He has published with his collaborators and students as of 2008 several papers concerning the chemical signatures preserved in archaeological soils and demonstrated that chemical signatures are able to answer numerous challenging archaeological as well as environmental questions (see Hejcman et al. 2013 for the list of relevant publications). $\mathrm{He}$ is also interested in the history of agriculture and the use of modern methods employed in animal nutrition and ethnography research. He has proposed a new "year-round livestock grazing model" for deforestation in prehistory. His future research activities consist of planting of prehistoric crops and determination of their nutritive value.

Michal Hejcman is a member of the editorial board of the international journals Grass and Forage Science, Plant Soil and Environment and Interdisciplinaria Archaeologica Natural Sciences in Archaeology. He has published with his colleagues and students 88 papers in scientific journals with an impact factor from 2003 to 2013.

\section{References}

HEJCMAN, M., HEJCMANOVÁ, P, HLÁSNÁ-ČEPKOVÁ, P., HORÁK, J., KARLÍK, P., PAVLŮ, V., ROSENBERG, R., SOUČKOVÁ, K., STAŇKOVÁ, P., STEJSKALOVÁ, M. 2013: Environmental Archaeology at the Czech University of Life Sciences Prague - Application of New Methods for Interdisciplinary Research. Interdisciplinaria Archaeologica - Natural Sciences in Archaeology IV/2/2013, 223-231.

HEJCMAN, M., KLAUDISOVÁ, M., HEJCMANOVÁ, P., PAVLŮ, V., JONES, M. 2009: Expansion of Calamagrostis villosa in sub-alpine Nardus stricta grassland: Cessation of cutting management or high nitrogen deposition? Agriculture, Ecosystems and Environment 129, 91-96.

HEJCMAN, M., KLAUDISOVÁ, M., ŠTURSA, J., PAVLŮ, V., HAKL, J., SCHELlBERG, J., HEJCMANOVÁ, P., RAUCH, O., VACEK, S. 2007: Revisiting a 37 years abandoned fertilizer experiment on Nardus grassland in the Czech Republic. Agriculture, Ecosystems and Environment 118, 231-236.

HEJCMAN, M., NEŽERKOVÁ, P., PAVLU゚, V., GAISLER, J., LOKVENC, T., PAVLUீ, L. 2005: Regeneration of Nardus stricta subalpine grasslands in the Giant Mountains (Krkonoše). Acta Societatis Botanicorum Poloniae 74, 253-258.

HEJCMAN, M., PAVLŮ, V., HEJCMANOVÁ, P., GAISLER, J., HAKL, J., RAUCH, O. 2006: Farmer decision making and its effect on the subalpine grassland succession in the Giant Mountains, Czech Republic. Acta Societatis Botanicorum Poloniae 75, 165-174.

SEMELOVÁ, V., HEJCMAN, M., PAVLU゚, V., VACEK, S., PODRÁZSKÝ, V. 2008: The Grass Garden in the Giant Mts. (Czech Republic): residual effect of long-term fertilization after 62 years. Agriculture, Ecosystems and Environment 123, 337-342. 
